\title{
Numerical Taxonomy and Emended Description of Renibacterium salmoninarum
}

\author{
By M. GOODFELLOW, ${ }^{*}$ T. M. EMBLEY ${ }^{1,2}$ and B. AUSTIN 2,3 \\ ${ }^{1}$ Department of Microbiology, The Medical School, Framlington Place, Newcastle upon Tyne \\ $N E 24 H H, U K$ \\ ${ }^{2}$ Ministry of Agriculture, Fisheries and Food, Directorate of Fisheries Research, Fish Diseases \\ Laboratory, Weymouth, Dorset DT4 8UB, UK \\ ${ }^{3}$ Department of Brewing and Biological Sciences, Heriot-Watt University, Chambers Street, \\ Edinburgh EHI IHX, UK
}

(Received 5 March 1985; revised 22 May 1985)

Forty-four strains of Renibacterium salmoninarum and 12 representative cultures of Actinomyces, Arthrobacter, Lactobacillus, Microbacterium, Micrococcus, Planococcus, Rothia and Listeria denitrificans were compared using numerical taxonomic techniques based upon 86 unit characters. Data were examined using the simple matching $\left(S_{S M}\right)$ and Jaccard $\left(S_{J}\right)$ coefficients, and clustering was achieved using the unweighted pair group method with arithmetic averages (UPGMA) technique. Cluster composition was barely affected by the statistics used, or by the test error, which was estimated at $0 \cdot 36 \%$. The renibacteria formed a distinct and homogeneous cluster and were distinguished from the marker cultures by a characteristic API-ZYM profile. An emended description of $R$. salmoninarum is presented, based on the numerical data and the results of recent chemical and microbiological studies.

\section{INTRODUCTION}

Bacterial kidney disease (BKD; Dee disease; corynebacterial kidney disease) is an important infectious disease of hatchery-reared salmonid fish (Fryer \& Sanders, 1981). The causal organism has been associated with Corynebacterium (Ordal \& Earp, 1956; Smith, 1964; Vladík et al., 1974; Sanders \& Fryer, 1978), Listeria (Bullock et al., 1975) and with coryneform bacteria generally (Bullock \& Stuckey, 1975), but is currently classified in the monospecific genus Renibacterium, mainly on the basis of chemical properties derived from an analysis of a few strains (Sanders \& Fryer, 1980). Subsequent chemotaxonomic studies (Collins, 1982; Embley et al., 1983; Kusser \& Fiedler, 1983) have supported the integrity of Renibacterium salmoninarum, which has been tentatively assigned to the actinobacteria (Goodfellow \& Cross, 1984), an aggregate group of actinomycetes encompassing fermentative actinomycetes and established coryneform taxa.

Little is known about the relationship of renibacteria to other Gram-positive organisms that have DNA relatively rich in guanine $(\mathrm{G})$ plus cytosine $(\mathrm{C})$ and lysine as the diamino acid of the wall peptidoglycan (Goodfellow \& Cross, 1984), though an affinity with Listeria denitrificans has been postulated on chemotaxonomic grounds (Collins et al., 1983). In the present study representatives of $R$. salmoninarum, including the type strain, were the subject of numerical phenetic analyses designed to determine the homogeneity of the taxon and its affinity, if any, with representative actinobacteria and lactobacilli.

\section{METHODS}

Cultures and maintenance. Forty-four $R$. salmoninarum and related strains and 12 marker cultures were obtained from either private or public culture collections (Table 1). The organisms were maintained as frozen glycerol 


\section{Table 1. Bacterial strains}

Lab. no.

127

K 114

K 112

K 116

$\mathrm{K} 28$ to $\mathrm{K} 32$

$\mathrm{K} 81$ to $\mathrm{K} 83$

K96

K95

$\mathrm{K} 102$

K91

K 104

K92

K93

K52

K53, K54

$\mathrm{K} 56$ to $\mathrm{K} 63$,

K 70, K 72,

K 73, K84,

K $86, \mathrm{~K} 87$

K89

128

K25

K 26

K35

K42

K43

K44

K46

K47

K48

K49

K50

K75

K 76

K 77, K 79,

K80

K 78

K90
Name as received

*Actinomyces viscosus

* Arthrobacter aurescens

* Arthrobacter globiformis

* Arthrobacter nicotianae

Corynebacterium sp. KD

Corynebacterium sp. KD

*Lactobacillus brevis

* Lactobacillus casei

* Lactobacillus curvatus

* Listeria denitrificans

* Microbacterium lacticum

* Micrococcus luteus

* Planococcus citreus

* Renibacterium salmoninarum

$R$. salmoninarum

R. salmoninarum

R. salmoninarum

* Rothia dentocariosa

KDM (kidney disease micro-organism)

KDM

KDM

KDM

KDM

KDM

KDM

KDM

'Dee Disease'

'Dee Disease'

KDM

KDM

KDM

KDM

KDM

KDM
Source and

collection no. $\dagger$

ATCC 15987

NCIB 8912

NCIB 8907

NCIB 9458

Baudin-Laurençin;

BL3, BL4, BL7, BL8

Baudin-Laurençin;

BL1, BLl1, BL12

NCDO 1749

NCDO 161

NCIB 9710

ATCC 14870

NCIB 8450

NCIB 9278

NCMB 1493

ATCC 33209

J. L. Fryer; RB173,

Cole river isolate

Laboratory isolates

Laidler; M213

ATCC 17931

Evelyn; KDB-897

NCMB 1113

Spacey

Paterson; AP-75

Groman; 6.0

Groman; 6.12

NCMB 1111

NCMB 1112

NCMB 1114

NCMB 1115

Hastein; A57/80

Souter; WS-1

Souter; FQ-1.75

Souter; KLAV-75,

NISQ-80, FO-RBT-12

Souter; SOC-3

Bruno; LF
Isolated from

Hamster; peridontal disease

Oncorhynchus kisutch (France)

Salmonid fish (France)

Human faeces

Cheese

Milk

Water

Oncorhynchus tschawytscha

Salmonid fish (USA)

Salmo salar (England)

Salmo salar (England)

Human; dental caries

Oncorhynchus nerka (Canada)

Salmo gairdneri

S. gairdneri (England)

S. salar (Canada)

O. nerka (Canada)

Salmonid fish (USA)

Salmo sp.

Salvelinus fontinalis

S. salar

S. salar

Salmonid fish (Norway)

Salmo sp. (Canada)

Salvelinus fontinalis (Canada)

$S$. gairdneri (Canada)

O. nerka (Canada)

Salmonid fish (Scotland)

* Type strain.

† Sources: ATCC, American Type Culture Collection, Rockville, Md., USA; NCDO, National Collection of Dairy Organisms, National Institute for Research in Dairying, Shinfield, Reading, UK ; NCIB and NCMB, now National Collection of Industrial and Marine Bacteria, Aberdeen, UK; Dr F. Baudin-Laurençin, Laboratoire National de Pathologie des Animaux Aquatiques, Brest, France; Dr D. Bruno, Department of Agriculture and Fisheries for Scotland, Aberdeen, UK ; Dr T. P. T. Evelyn, Department of Fisheries and the Environment, Pacific Biological Station, Nanaimo, Canada; Dr J. L. Fryer, Department of Microbiology, Oregon State University, USA; Dr D. Groman, College of Forestry, Wildlife and Range Sciences, University of Idaho, USA; Dr T. Hastein, National Veterinary Institute, Oslo, Norway; Mr T. Laidler, Veterinary Investigation Centre, Penrith, Cumbria, UK; Dr W. D. Paterson, Connaught Laboratories, Willowdale, Canada; Dr B. Souter, Freshwater Institute, Winnipeg, Canada; Mrs B. Spacey, Wellcome Research Laboratory, Beckenham, Kent, UK.

suspensions at $-20^{\circ} \mathrm{C}$ (Wellington \& Williams, 1979) and on plates of a semi-defined medium (SDM; Embley et al., 1982) supplemented with ascorbic acid $(0.05 \%, \mathrm{w} / \mathrm{v})$, haemin $(0.0002 \%, \mathrm{w} / \mathrm{v})$, inositol $(0.0001 \%, \mathrm{w} / \mathrm{v})$, sodium bicarbonate $(0.04 \%, w / v)$, sodium chloride $(0.1 \%, w / v)$ and thiamin $(0.0005 \%, w / v)$ at room temperature. These latter stocks were subcultured every two weeks and checked for purity from Gram-stained smears (Hucker \& Conn, 1923). 
Collection of data. Each strain was examined for 104 unit characters (Table 2) based on an array of biochemical, degradative, enzymic, morphological and tolerance tests. The biochemical, degradative and morphological tests were done in Petri dishes. Inocula from 4 to $8 \mathrm{~d}$ modified SDM plates were streaked over the surface of test media (four organisms per plate). The tolerance tests were done in polystyrene Replidishes (Sneath \& Stevens, 1967) using a multiloop inoculation procedure (Alderson, 1982). Thus, master plates were prepared by dispensing 1 to $2 \mathrm{ml}$ of each bacterial suspension into the wells of Replidishes and a multiloop inoculator, consisting of an aluminium template $(12 \times 12 \times 0.6 \mathrm{~cm})$ carrying 25 nichrome inoculating loops (Medical Wire and Equipment Co., Potley, Wilts, UK), was used to transfer $5 \mu \mathrm{l}$ of each suspension to the test media. The bacterial suspensions were prepared in distilled water using 4 to $8 \mathrm{~d}$ growth from modified SDM plates; suspensions were diluted to give an $\mathrm{OD}_{625}$ of approximately 0.5 , i.e. $10^{6}$ to $10^{8}$ cells $\mathrm{ml}^{-1}$, unless otherwise stated.

Nearly all of the strains grew well on test media, adjusted to $\mathrm{pH} 6.8$ when necessary, at $15^{\circ} \mathrm{C}$. Actinomyces riscosus ATCC 15987 and Rothia dentocariosa ATCC 17931 were incubated at $30^{\circ} \mathrm{C}$ as they did not grow at the lower temperature. The remaining marker strains were incubated at both 15 and $30^{\circ} \mathrm{C}$ for all but the temperature tests in order to determine the effect of temperature on the numerical classifications. Modified SDM agar was used as the basal medium throughout. Tests were repeated when ambiguous or clearly unexpected results were obtained. Tests were read weekly up to $21 \mathrm{~d}$ unless stated otherwise. Data for computation were taken from the final test reading unless stated to the contrary.

API tests. API-ZYM kits (API Laboratory Products) were used to determine the ability of the strains to produce the enzymes listed in Table 2. Cupules were inoculated with two drops of dense bacterial suspensions $\left(\mathrm{OD}_{625} 2-3\right)$ in distilled water. Reproducible results were obtained with the renibacteria after $6 \mathrm{~h}$ at $15^{\circ} \mathrm{C}$, and with the marker strains after $12 \mathrm{~h}$ at $15^{\circ} \mathrm{C}$ and $6 \mathrm{~h}$ at $30^{\circ} \mathrm{C}$. Tests were read as instructed by the manufacturer. The kits were examined under a high density lamp in order to eliminate any yellow coloration due to an excess of Fast Blue (ZYM B reagent). Weak positive results were confirmed by comparing treated against control kits containing distilled water. Both weak and strong reactions were scored positive.

Biochemical tests. Catalase (Cowan, 1974) and oxidase production (Kovacs, 1956) were detected on 4 to $8 \mathrm{~d}$ cultures. Phosphatase activity (Wilkinson \& Jones, 1977) was examined after $14 \mathrm{~d}$.

Colonial properties. Pigmentation was recorded after 7 and $14 \mathrm{~d}$. Motility was examined in wet preparations from $7 \mathrm{~d}$ modified SDM broth cultures at $\times 400$ magnification under phase contrast.

Degradation tests. The degradation of adenine, chitin, hypoxanthine, tyrosine, xanthine $($ all $0.5 \%, w / v)$, casein $(1 \%, w / v ;$ skimmed milk), elastin $(0.3 \%, w / v)$, guanine and testosterone $(0.1 \%$, w $/ v)$ was detected as clearing of the insoluble compounds from in and around areas of growth. Plates of modified SDM medium supplemented with Tweens 20,40, 60 and $80(1 \%, v / v)$ were examined for opacity (Sierra, 1957), and lecithin $(1 \%, v / v)$ and tributyrin $\left(1_{/ 0}^{\circ}, v / v\right)$ plates for clearing. Starch degradation was observed after $21 \mathrm{~d}$ by flooding plates with iodine solution (Cowan, 1974) and scoring zones of clearing as positive. Hyaluronidase and chondroitin sulphatase $\left(400 \mu \mathrm{g} \mathrm{ml} \mathrm{m}^{-1}\right.$; Schofield \& Schaal, 1981) activities were detected when 21 d plates were flooded with 2 M-acetic acid, left for $15 \mathrm{~min}$ and examined for clear zones around bacterial growth. Degradation of DNA and RNA $(0 \cdot 2 \%$ w $/ \mathrm{v}) \mathrm{was}$ observed when 21 d plates were flooded with $1 \mathrm{M}-\mathrm{HCl}$; clearance zones were recorded as positive. Blackening of test media indicated a positive result for aesculin and arbutin degradation $(0.5 \%$, w/v; Broom \& Sneath, 1981$)$.

Growth tests. Growth at $45^{\circ} \mathrm{C}$ was recorded after 2 weeks, and that at 4,15 and $30^{\circ} \mathrm{C}$ after 4 weeks. Resistance to bile salts, dyes and inorganic chemical inhibitors at various concentrations (Table 2) was scored weekly for 3 weeks by comparing growth in the presence of the inhibitory compound against that in the negative control; any sign of inhibition was scored negative. The first readable result was taken for computation. The same procedure was followed with the antibiotics but in this case Replidishes were read after 7,10 and $14 \mathrm{~d}$ at $15^{\circ} \mathrm{C}$, and after 3 and $7 \mathrm{~d}$ at $30^{\circ} \mathrm{C}$. Growth at $\mathrm{pH} 5.8$ and $\mathrm{pH} 7.8$ was examined in buffered $(0.5 \mathrm{M}$-potassium phosphate) media for 4 weeks.

Utilization of 4-methylumbelliferone $(4 M U)$ deritatives. Samples $(50 \mu \mathrm{l})$ of dense bacterial suspensions $\left(\mathrm{OD}_{625} 2-\right.$ 3) in buffer were added to equal volumes of 4-methylumbelliferyl fluorogenic substrates (Koch-Light) in microtitre plate wells which were then covered with plastic lids (Grange \& Clarke, 1977; Grange, 1978). The substrates were dissolved in $2 \mathrm{ml}$ dimethyl sulphoxide (Sigma) to give $0.02 \mathrm{M}$ solutions of acyl ester and $0.04 \mathrm{M}$ solutions of glycoside and sulphate substrates (Grange, 1978); the stock solutions were stored at $-20^{\circ} \mathrm{C}$. Working solutions were prepared by adding $0.2 \mathrm{ml}$ stock solution to $9.8 \mathrm{ml}$ sterile buffer. Glycoside substrates were prepared in phosphate buffer at $\mathrm{pH} 5.4$, and acyl ester and sulphate substrates in Dulbecco A buffer at $\mathrm{pH} 7.4$ as recommended by Grange (1978). Glycosidase activity was read after $18 \mathrm{~h}$, the hydrolysis of acyl esters after 6,12 and $18 \mathrm{~h}$, and sulphatase activity after 12 and $18 \mathrm{~h}$. After incubation, a drop of $1 \mathrm{M}-\mathrm{NaOH}$ was added to each well containing glycoside substrates as this caused any $4 \mathrm{MU}$ released by enzyme activity to fluoresce intensively under long wave $(366 \mathrm{~nm})$ UV light. The remaining tests were read without modifying the $\mathrm{pH}$ of the reaction mixture as the $4 \mathrm{MU}$ conjugates of these substrates are known to hydrolyse spontaneously at high $\mathrm{pH}$ giving false positive results (Grange, 1978).

Coding of data. Many of the characters existed in one of two mutually exclusive states and were scored plus (1) or 
minus (0). The character states for pigmentation were mutually exclusive and were scored plus (1) for the state exhibited and minus ( 0 ) for the remaining states (Sneath \& Sokal, 1973). Quantitative multistate characters, such as tolerance to chemical inhibitors, were coded using the additive method of Sneath \& Sokal (1973). Eighteen tests were deleted from the original data matrix because they were constant in the matrix. The final data matrix, therefore, contained data for 56 strains incubated at $15^{\circ} \mathrm{C}$ and 86 unit characters (Table 2). An enlarged matrix containing the information obtained with the 12 marker strains incubated at $30^{\circ} \mathrm{C}$ was also prepared.

Computer analysis. Data were examined using the Clustan IC program (Wishart, 1978) on an IBM 370/180 computer using the simple matching coefficient $\left(S_{S M}\right.$; Sokal \& Michener, 1958), which includes both positive und negative matches, and the Jaccard coefficient $\left(S_{J} ;\right.$ Sneath, 1957), which includes positive matches only. Clustering on each of the coefficients was achieved using the unweighted pair group method with the arithmetic averages (UPGMA) algorithm (Sneath \& Sokal, 1973); the results are presented as dendrograms. Cophenetic discrepancies, that is the lack of correlation between respective similarity values in a matrix and its corresponding dendrogram, were assessed for each coefficient using the correlation coefficient ( $r$; see Sneath, 1978).

Test reproducibility. The test results for the nine duplicate cultures and their partners (Table 3) were compared for the 86 unit characters and an estimate of individual test variance $\left(s_{1}^{2}\right)$ was calculated (formula $15 ;$ Sneath $\&$ Johnson, 1972). The average test variance was determined to obtain a pooled variance $\left(s^{2}\right)$ which was used to calculate the average probability ( $p$ ) of an erroneous test result (formula 4; Sneath \& Johnson, 1972). The similarity between duplicates was estimated by computation of the $S_{S M}$ coefficient.

\section{RESULTS}

\section{Criteria of goodness}

Inclusion of duplicate strains in the analysis enabled experimental test error to be calculated. The average probability $(p)$ of an erroneous test result was $0.72 \%$ calculated from the pooled variance $\left(s^{2}=0.007\right)$ of all the unit characters scored for the duplicate strains grown at $15^{\circ} \mathrm{C}$. The nine pairs of duplicate strains showed a mean observed similarity of around $98.5 \% S_{S M}$. Values of $s_{1}^{2}$ ranged from zero for the majority of the tests, through 0.055 for alkaline phosphatase, catalase, oxidase and esterase $\left(\mathrm{C}_{4}\right)$ production, casein and Tween 40 degradation, and growth at pH 5.8 and 7.8 and in the presence of methylene blue $(0.0001 \%, w / v)$, to 0.11 for growth in the presence of Nile blue sulphate $(0 \cdot 001 \%, \mathrm{w} / \mathrm{v})$.

The correlation coefficients $(r)$ between the similarity matrix and corresponding dendrograms were 0.98 for the $S_{S M}$ and 0.99 for the $S_{J}$ coefficients. Both of these values are very high and well within acceptable limits for a study using UPGMA.

\section{Clustering of strains using the $S_{S M}$ coefficient and the UPGMA algorithm}

The classification based on the $S_{S M}$, UPGMA analysis is described in detail for, in general, it gave the most compact clusters and aggregate clusters. Thus, all but one of the 56 strains were recovered in three aggregate clusters defined at the $66 \%$ similarity $(S)$ level or above (Fig. 1). The remaining strain, Planococcus citreus NCMB 1493, formed a single member aggregate cluster which showed its closest similarity to aggregate cluster 3.

The first aggregate cluster, defined at the $72 \% S$-level, contained 44 strains received as Corynebacterium sp. KD, Renibacterium salmoninarum, kidney disease or Dee disease microorganisms, and Actinomyces viscosus ATCC 15987, Micrococcus luteus NCIB 9278 and Rothia dentocariosa ATCC 17931. All of the fish pathogens were designated Renibacterium salmoninarum as they formed a tight cluster defined at the $93 \% S$-level. The three single member clusters shared only a loose relationship to one another and to the $R$. salmoninarum strains.

The second aggregate cluster, delineated at the $76 \% \mathrm{~S}$-level, contained 3 lactobacilli including Lactobacillus brevis NCDO 1749 and Lactobacillus casei NCDO 161 which joined at the $85 \%$ $S$-level. The remaining strain, Lactobacillus curvatus NCIB 9710, was united with the other two at the $69 \% S$-level. The final aggregate cluster, cut-off at the $69 \% S$-level, contained 5 single member clusters, Arthrobacter aurescens NCIB 8912, Arthrobacter globiformis NCIB 8907, Arthrobacter nicotianae NCIB 9458, Listeria denitrificans ATCC 14870 and Microbacterium lacticum NCIB 8450. 


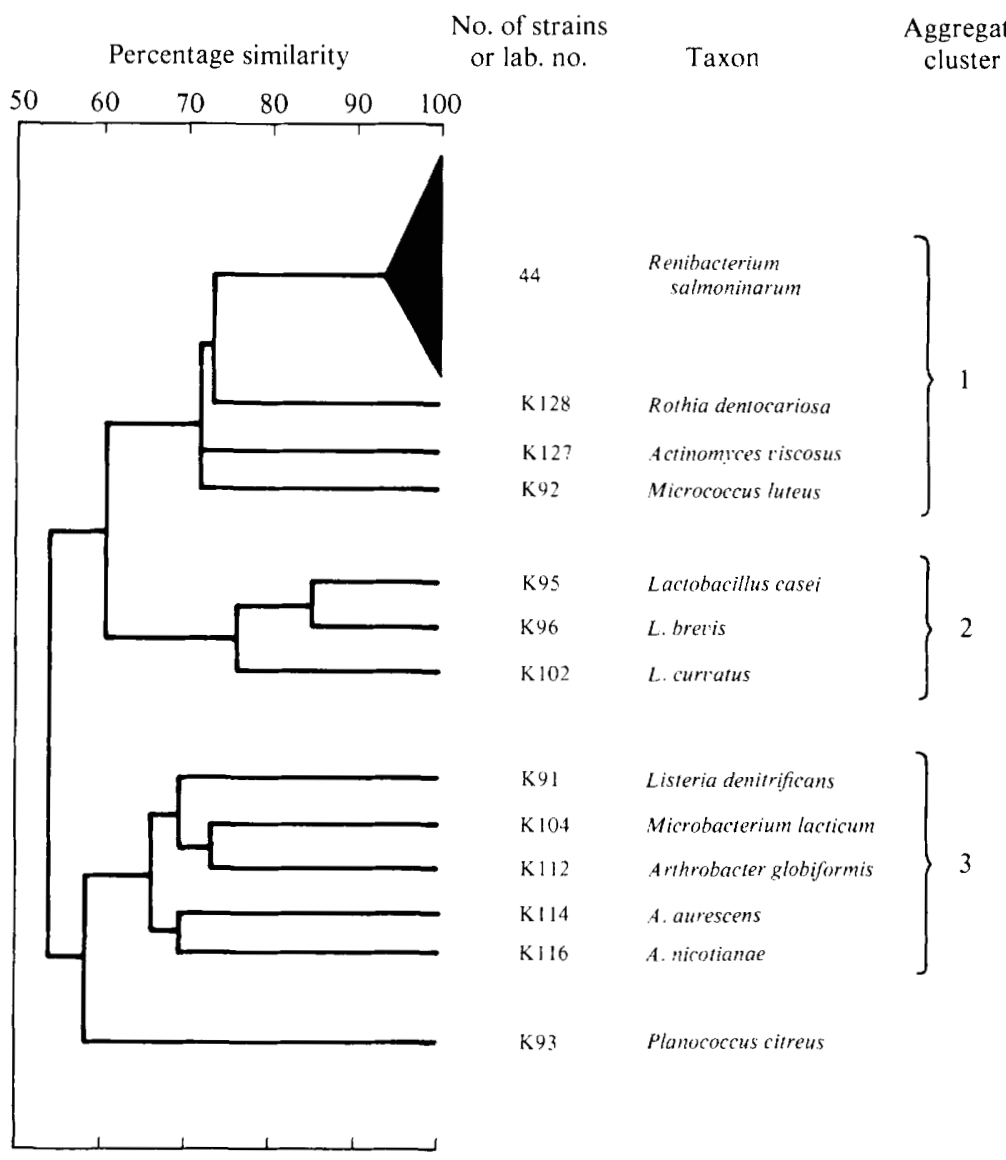

Fig. 1. A simplified dendrogram showing the relationships between clusters recovered in the $S_{S M}$. UPGMA analysis.

Clustering of strains using the $S_{J}$ coefficient and the UPGMA algorithm

The compositions of both the $R$. salmoninarum cluster and the three aggregate clusters were only marginally affected when the data were analysed using the $S_{J}$ coefficient and the UPGMA algorithm (Fig. 2). However, aggregate cluster 1 , defined at the $36 \% S$-level, contained 46 as opposed to 47 strains as $M$. luteus NCIB 9278 was recovered on the periphery of aggregate cluster 3. The renibacteria formed a compact cluster at the $87 \% S$-level apart from $R$. salmoninarum K42 which joined the cluster at the $76 \% S$-level. Actinomyces viscosus ATCC 15987 and Rothia dentocariosa ATCC 17931 were again sharply separated from one another and from the $R$. salmoninarum cluster. Aggregate cluster 2 was again recognized but now showed a close similarity to aggregate cluster 3. Within the latter the three Arthrobacter strains formed a cluster at the $57 \% S$-level.

\section{Characterization of Renibacterium salmoninarum}

The properties of the renibacteria and marker strains are shown in Table 2, together with characters of potential diagnostic value. It is particularly interesting that the majority of the renibacteria gave a characteristic profile of positive reactions with the API-ZYM tests, with only $R$. salmoninarum $\mathrm{K} 25$ and $\mathrm{K} 42$ giving negative responses for alkaline phosphatase and 2-Dmannosidase, respectively. Indeed, the results of the API-ZYM tests seem to be sufficiently diagnostic to distinguish renibacteria from all of the other test organisms. 


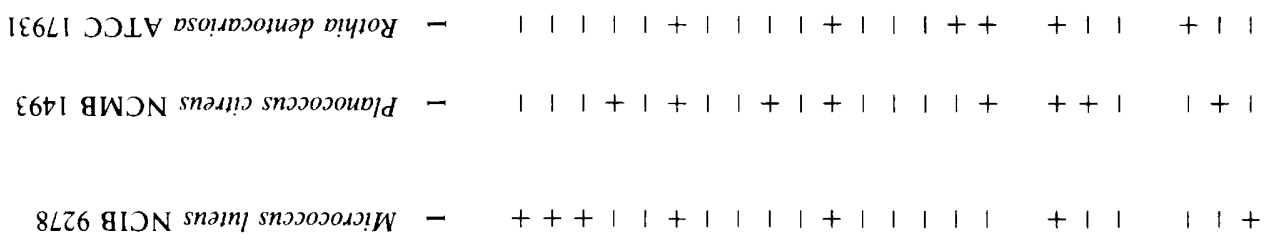

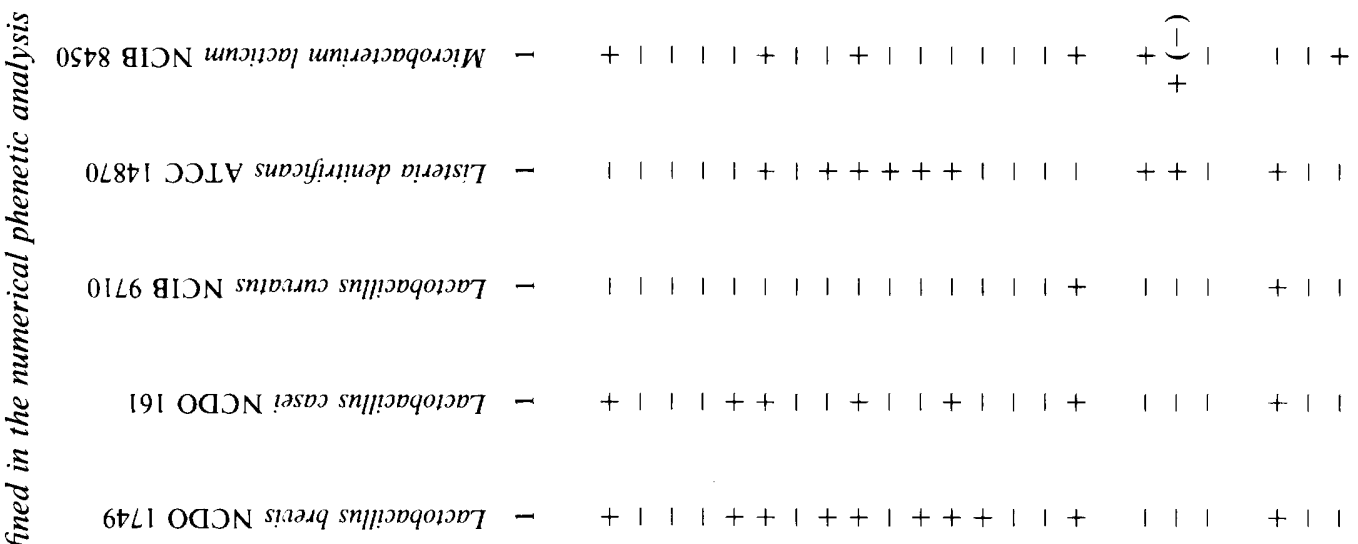

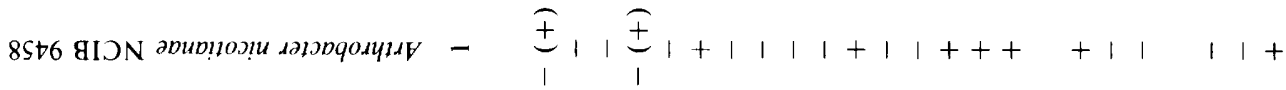
$\frac{1}{2}$

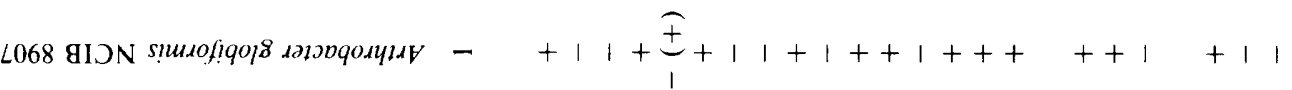

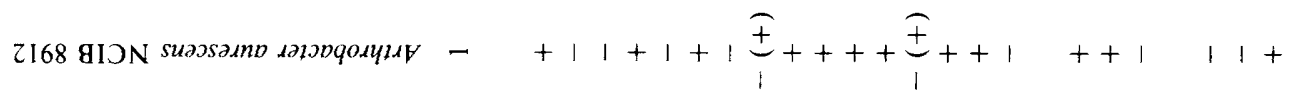

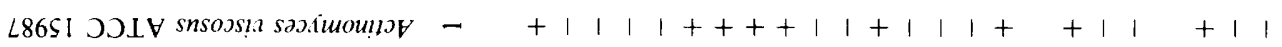

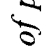

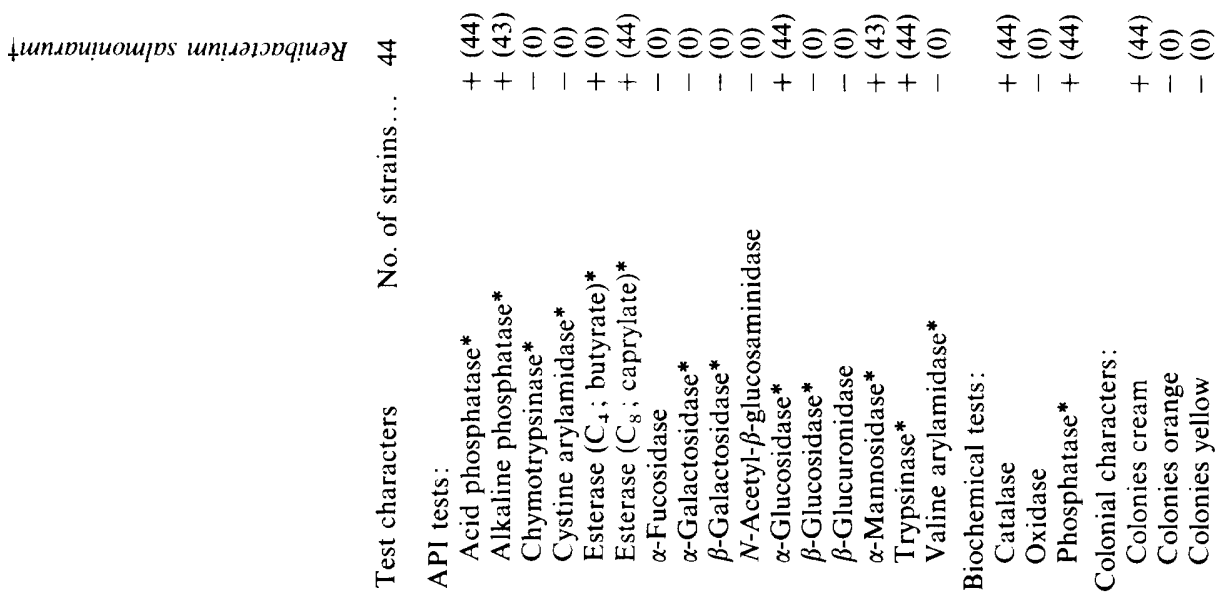




$$
\begin{aligned}
& 1 \quad 1+t+11+1111111+11111111+t+t+1+11
\end{aligned}
$$

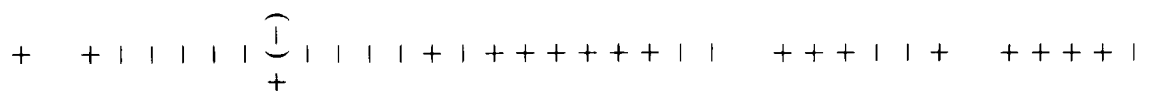

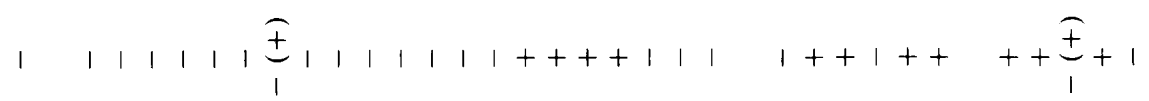

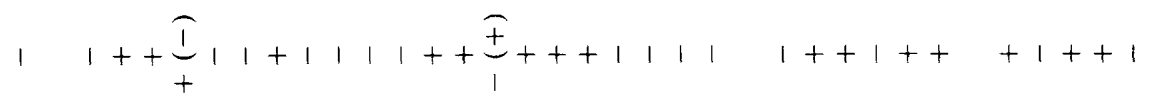

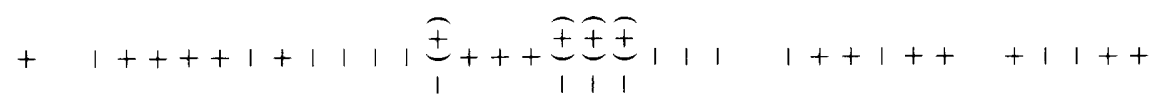

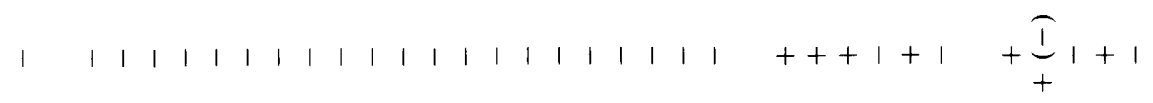

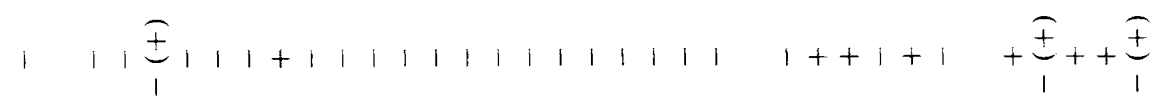

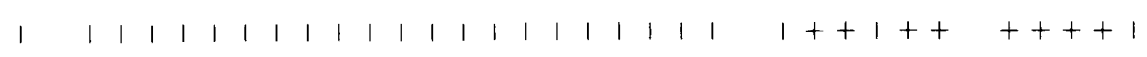

$$
\begin{aligned}
& 1+\overparen{I}_{1}+11+1++1++1++++1++1++1++++1++ \\
& 1+t+1|1| 1++1 \mid+1+t++1++1++1+++1+\frac{T}{t}+1 \\
& 1+t++1++++++\underbrace{T}_{t}+\underbrace{I}_{1}+1+11+++++1+++1++\frac{T}{t} \\
& 1 \quad 1+1+11+1|1| 1 \mid+1+t+++1 \quad 1 \quad 1 \quad 1+1+t \quad 1 \quad 1 \quad 1 \quad 11
\end{aligned}
$$

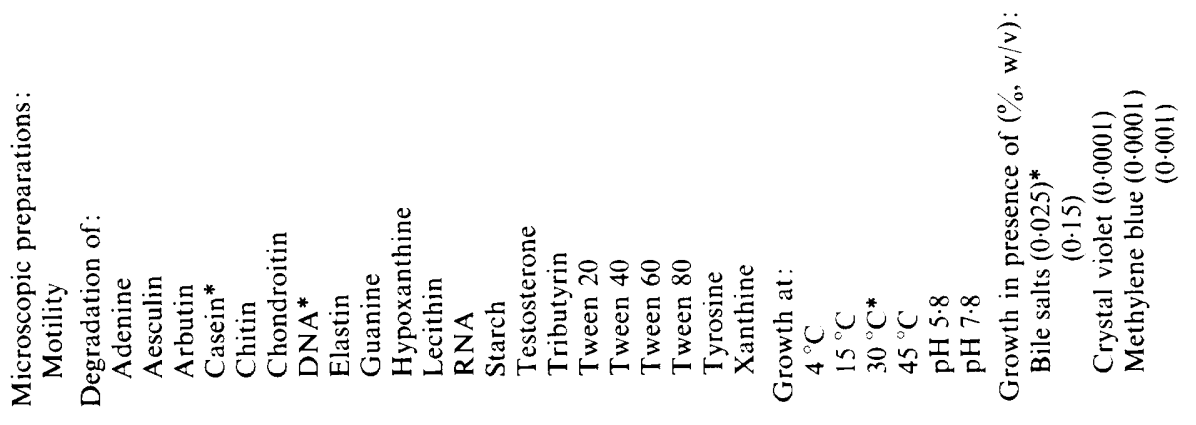




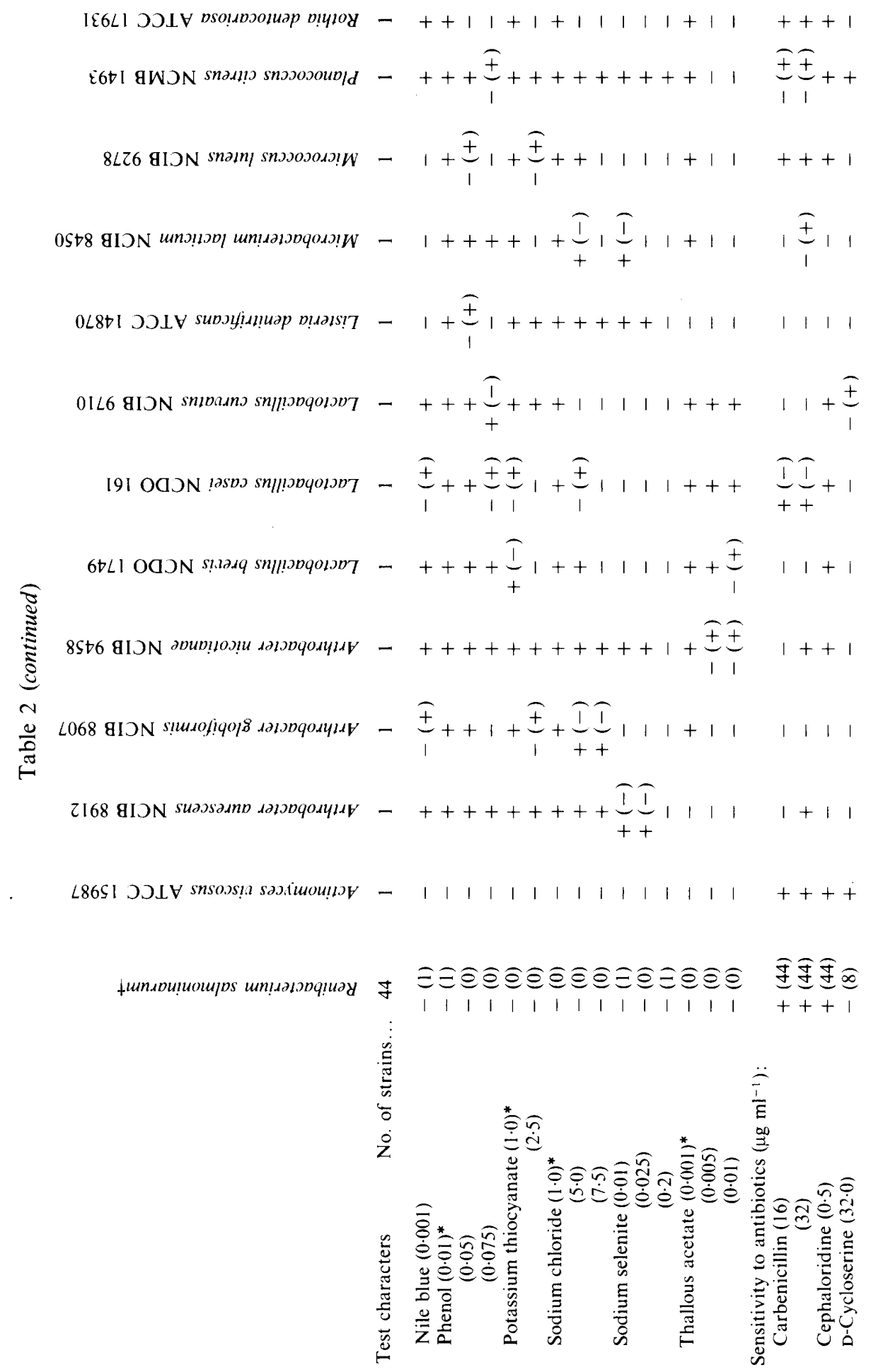




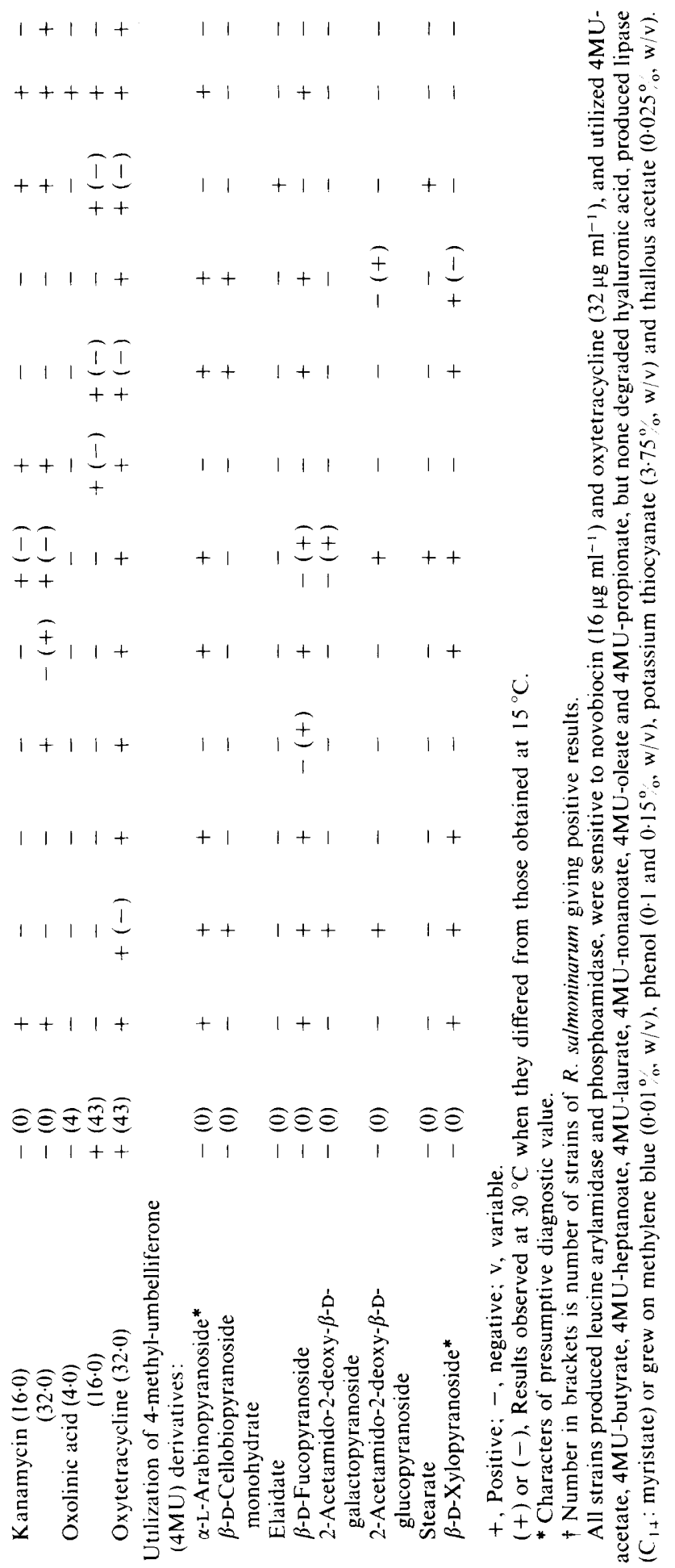




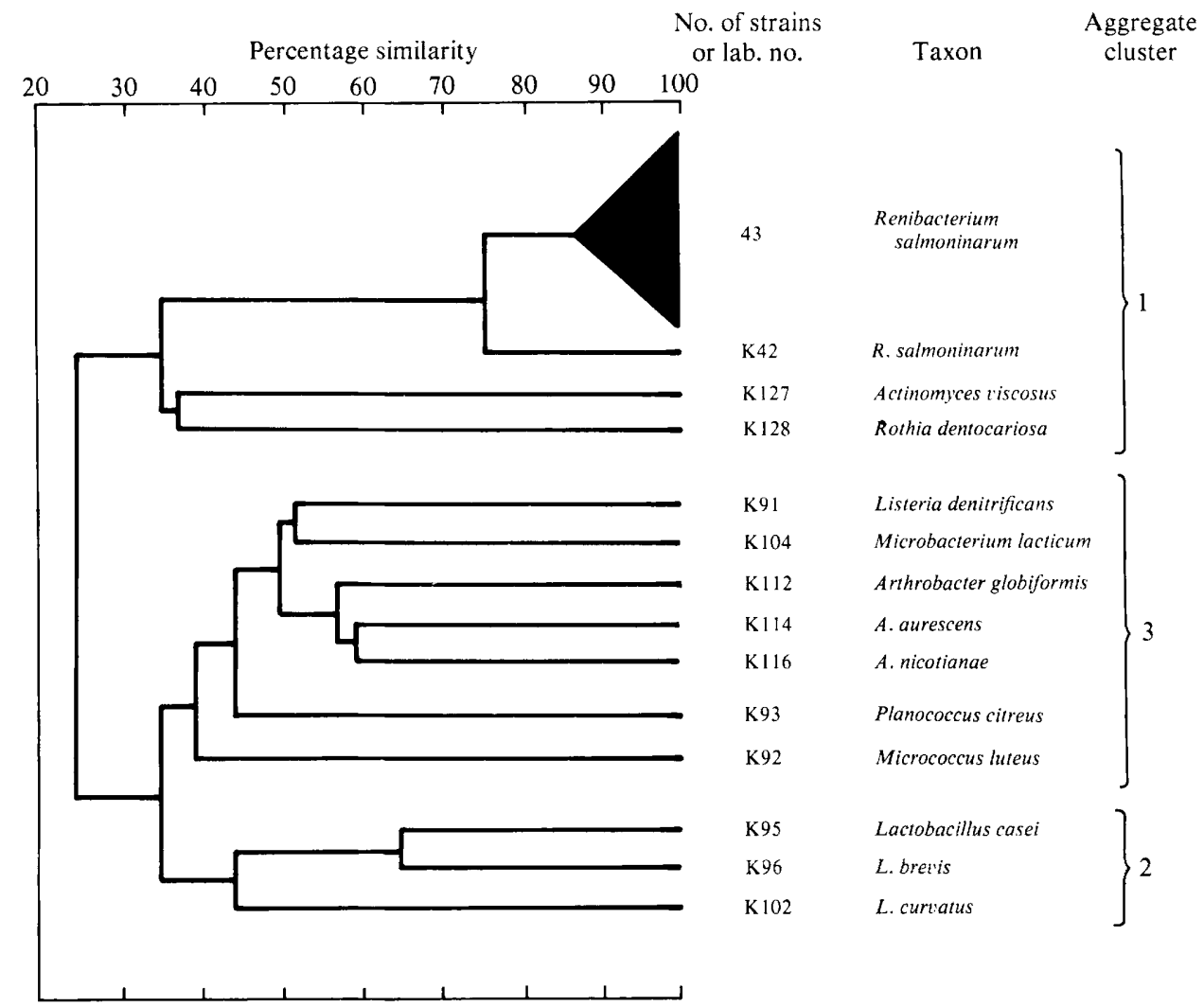

Fig. 2. A simplified dendrogram showing the relationships between clusters recovered in the $S_{J}$, UPGMA analysis.

Table 3. Overall similarity values between duplicate sets of marker strains

Strains were incubated at $15^{\circ} \mathrm{C}$ and $30^{\circ} \mathrm{C}$ for tests included in the numerical phenetic analyses based on the $S_{J}$ and $S_{S M}$ coefficients and UPGMA clustering.

\begin{tabular}{lcc}
\multicolumn{1}{c}{ Coefficient... } & \multicolumn{2}{c}{ Percentage similarities } \\
\cline { 2 - 3 } Duplicate cultures & $S_{J}$ & $S_{S M}$ \\
Arthrobacter aurescens NCIB 8912 & 84 & 88 \\
Arthrobacter globiformis NCIB 8907 & 85 & 92 \\
Lactobacillus brevis NCDO NCIB 9458 & 88 & 93 \\
Lactobacillus casei NCDO 161 & 91 & 97 \\
Lactobacillus curvatus NCIB 9710 & 65 & 86 \\
Listeria denitrificans ATCC 14870 & 79 & 94 \\
Microbacterium lacticum NCIB 8450 & 84 & 92 \\
Micrococcus luteus NCIB 9278 & 77 & 90 \\
Planococcus citreus NCMB 1493 & 83 & 93 \\
\end{tabular}

\section{Effect of temperature on the numerical classification of marker cultures}

The results obtained when 10 of the marker cultures were examined at $30^{\circ} \mathrm{C}$ were in most instances similar to those obtained at $15^{\circ} \mathrm{C}$ (Table 2). In the $S_{S M}$ analysis, the duplicate strains generally showed similarity values of over $90 \%$, slightly lower values being recorded for the duplicate cultures of $A$. aurescens and $L$. casei (Table 3 ). The relationships between the marker cultures were only marginally altered when the data obtained at $30^{\circ} \mathrm{C}$ were added to the data 
matrix though L. casei NCDO 161 joined with L. brevis NCDO 1749 at the $88 \% S$-level, and thereby showed a greater similarity to the latter than to its own duplicate incubated at $15^{\circ} \mathrm{C}$.

In the corresponding $S_{J}$ analysis, the $S$-levels obtained between the two sets of duplicate cultures were $77 \%$ or above apart from the cultures of $L$. casei, which united at the $65 \% S$-level. Once again the detailed relationships between the marker cultures were only slightly altered when the data obtained at $30^{\circ} \mathrm{C}$ were considered. However, L. casei NCDO 161 again showed a greater similarity with $L$. brevis NCDO 1749 at $30^{\circ} \mathrm{C}$ than with its own duplicate incubated at $15^{\circ} \mathrm{C}$.

\section{DISCUSSION}

The numerical phenetic classification of the test strains was only marginally affected by the coefficient of association $\left(S_{J}\right.$ or $S_{S M}$ ), or by the test error of $0.36 \%$. It was also encouraging that the clustering of the marker strains was only slightly influenced by the incubation temperature employed. The renibacteria, received from diverse sources under a variety of labels, formed a homogeneous cluster that was sharply separated from representative strains of Actinomyces, Arthrobacter, Lactobacillus, Microbacterium, Micrococcus, Planococcus, Rothia and Listeria denitrificans, all of which have DNA relatively rich in $\mathrm{G}+\mathrm{C}$, and lysine as the diamino acid of the wall peptidoglycan (Goodfellow \& Cross, 1984). It is evident that Renibacterium salmoninarum is a good species, a finding that is in excellent agreement with chemotaxonomic data (Embley et al., 1983; Kusser \& Fiedler, 1983). It was also significant, given the problems experienced in the diagnosis of bacterial kidney disease (Fryer \& Sanders, 1981), that the renibacteria could be distinguished from the other test strains by their API-ZYM profiles and by their reactions to a few simple biochemical tests. These diagnostic properties have already been used to identify renibacteria growing on selective isolation plates (Austin et al., 1983), and also serve to distinguish these organisms from Actinomyces pyogenes and Arcanobacterium haemolyticum (Schofield \& Schaal, 1981).

The $R$. salmoninarum cluster was loosely associated within an aggregate cluster with the type strains of Actinomyces viscosus, Arthrobacter nicotianae, Micrococctis luteus and Rothia dentocariosa. The low similarity found between $A$. viscosus and $R$. dentocariosa was in good agreement with the results of earlier numerical phenetic surveys (Holmberg \& Hallander, 1973; Schofield \& Schaal, 1981). However, $R$. salmoninarum can also be distinguished from other members of aggregate cluster 1 by chemical criteria (Embley et al., 1983). Thus, Actinomyces viscosus ATCC 15987 and Arthrobacter nicotianae NCIB 8907 have the peptidoglycan type A4 $\alpha$ (Schleifer \& Kandler, 1972; Weiss et al., 1981) and Micrococcus luteus NCIB 9278 and Rothia dentocariosa ATCC 17931 have peptidoglycan types A2 $\alpha$ and A3 $\alpha$, respectively (Schleifer \& Kandler, 1972), whereas Renibacterium salmoninarum ATCC 33209 has a unique variation of the A $3 \alpha$ type (Kusser \& Fiedler, 1983).

The possibility of close relationships between Lactobacillus and Renibacterium (Vladík et al., 1974), and between the latter and Listeria denitrificans (Collins et al., 1983) is not supported by the numerical phenetic data. It is also interesting that $R$. salmoninarum and $L$. denitrificans have markedly different peptidoglycan types (Fiedler \& Seger, 1983; Kusser \& Fiedler, 1983; Fiedler et al., 1984). The sharp separation of the lactobacilli from the actinobacteria included in the present study is in good agreement with the results of previous numerical taxonomic studies (Davis et al., 1969; Jones, 1975; Wilkinson \& Jones, 1977). The type strain of Paracoccus citreus also showed little overall similarity to either Renibacterium or the actinobacteria. These findings are not surprising as $16 \mathrm{~S}$ rRNA cataloguing data show that both lactobacilli and paracocci are not related to the actinomycetes but belong to the Bacillus-Clostridium phyletic line (Stackebrandt \& Woese, 1979, 1981). The relatively close relationship found between Arthrobacter aurescens NCIB 8912, Arthrobacter globiformis NCIB 8907 and Arthrobacter nicotianae NCIB 9458 in the $S_{J}$ and $S_{S M}$, UPGMA analyses is also in line with current trends in the taxonomy of these organisms (Stackebrandt et al., 1983).

It is timely to redescribe $R$. salmoninarum in the light of data derived from this and some recent studies (Sanders \& Fryer, 1980; Embley et al., 1982, 1983; Embley, 1983). 


\section{Emendation of Renibacterium salmoninarum Sanders and Fryer 1980}

(Re.ni.bac.te' rium L. n. renes the kidneys; Gr. neut. n. bakterion small rod; M.L. neut. $\mathrm{n}$. Renibacterium kidney bacterium. sal.mo.ni.na'.rum M.L. Salmoninae subfamily of the Salmonidae; M.L. gen. n. salmoninarum, of the Salmoninae.)

Aerobic, strongly Gram-positive, asporogenous, non-acid alcohol fast, non-encapsulated, non-motile short rods, 0.3 to 1.0 by 1.0 to $1.5 \mu \mathrm{m}$, often occurring in pairs. White to creamy yellow, circular, convex colonies of varying sizes are formed on cysteine serum agar. With Dorset egg medium, growth appears as a raised, smooth, shiny yellow layer and on Loeffler coagulated serum a creamy growth with a matt surface is produced. In cysteine serum broth, creamy yellow growth occurs only at the surface of the medium but uniformly turbid growth is formed in Mueller-Hinton broth. Growth in all of these media is slow, often requiring several weeks of incubation. Good growth can be obtained with a semi-defined medium (SDM) within $15 \mathrm{~d}$. On SDM agar, raised, smooth, shiny, creamy yellow colonies are found. Cysteine is required for growth. Growth is enhanced by albumin, blood, charcoal, serum and Tween 60 .

Growth is very slow at $5{ }^{\circ} \mathrm{C}$ and $22^{\circ} \mathrm{C}$ and absent at $30^{\circ} \mathrm{C}$. Optimal growth occurs between 15 and $18{ }^{\circ} \mathrm{C}$ and $\mathrm{pH} 5.8$ to 7.8 . Catalase positive (actively inhibited by $0.01 \mathrm{M}$-sodium azide), cytochrome oxidase negative. There is no apparent acid production from sugars. Does not liquefy gelatin. Proteolysis without any $\mathrm{pH}$ change is produced in litmus milk. Additional biochemical, enzymic and physiological properties are shown in Table 2.

The cell wall peptidoglycan contains alanine, glutamic acid, glycine and lysine as the diamino acid and is the unique A $3 \alpha$ type (Kusser \& Fielder, 1983). The principal cell wall sugar is glucose; arabinose, mannose and rhamnose are also present.

Produces unsaturated menaquinones with nine isoprene units as the predominant isoprenologue and has a very characteristic polar lipid pattern consisting of diphosphatidylglycerol, two major and six or seven uncharacterized glycolipids, and two unclassified minor phospholipids (Embley et al., 1983). The fatty acid profile contains major amounts of methylbranched acids with 12-methyltetradecanoic, 13-methyltetradecanoic and 14-methylhexadecanoic predominating (Embley et al., 1983). Mycolic acids are absent.

The $\mathrm{mol} \% \mathrm{G}+\mathrm{C}$ of the DNA is 53 to 54 .

Causes a slowly developing chronic infection of salmonid fish, characterized by grey-white, enlarged necrotic abscesses in the kidney. The organism has only been isolated from members of the Salmoninae, the char, salmon and trout, of the family Salmonidae.

Type strain: ATCC 33209.

The present study has gone some way towards clarifying the taxonomy of $R$. salmoninarum and has highlighted a number of properties that may prove to be of value in the identification of unknown strains. However, representative renibacteria need to be included in comparative taxonomic studies based on techniques such as $16 \mathrm{~S}$ rRNA cataloguing if the suprageneric affinities of Renibacterium are to be established.

The authors are greatly indebted to colleagues (Table 1) who kindly provided strains. T.M.E. gratefully acknowledges receipt of an SERC CASE award studentship.

\section{REFERENCES}

Alderson, G. (1982). Numerical and chemical classifcation of the genus Streptomyces. Ph.D. thesis, University of Newcastle upon Tyne, UK.

Austin, B., Embley, T. M. \& Goodfellow, M. (1983). Selective isolation of Renibacterium salmoninarum. FEMS Microbiology Letters 17, 111-114.

Broom, A. K. \& Sneath, P. H. A. (1981). Numerical taxonomy of Haemophilus. Journal of General Microbiology 126, 123-149.

Bullock, G. L. \& StuCKey, H. M. (1975). Fluorescent antibody identification and detection of the Coryne- bacterium causing kidney disease in salmonids. Journal of the Fisheries Research Board of Canada 32, 2224-2227.

Bullock, G. L., Stuckey, H. M. \& Wolf, K. (1975). Bacterial kidney disease of salmonid fish. Fish and Wildlife Service Fish Diseases Leaflet no. 41. Washington, DC: US Department of the Interior.

Collins, M. D. (1982). Lipid composition of Renibacterium salmoninarum (Sanders and Fryer). FEMS Microbiology Letters 13, 295-297.

Collins, M. D., Feresu, S. \& Jones, D. (1983). Cell 
wall, DNA base composition and lipid studies on Listeria denitrificans (Prevot). FEMS Microbiology Letters 18, 131-134.

Cowan, S. T. (1974). Cowan and Steel's Manual for the Identification of Medical Bacteria, 2nd edn. Cambridge: Cambridge University Press.

Davis, G. H. G., Fomin, L., Wilson, E. \& Newton, K. G. (1969). Numerical taxonomy of Listeria, streptococci and possibly related bacteria. Journal of General Microbiology 57, 333-348.

Embley, T. M. (1983). Aspects of the biology of Renibacterium salmoninarum. Ph.D. thesis, University of Newcastle upon Tyne, UK.

Embley, T. M., Goodfellow, M. \& Austin, B. (1982). A semi-defined growth medium for Renibacterium salmoninarum. FEMS Microbiology' Letters 14, 229301.

Embley, T. M., Goodfellow, M., Minnikin, D. E. \& Austin, B. (1983). Fatty acid, isoprenoid quinone and polar lipid composition in the classification of Renibacterium salmoninarum. Journal of Applied Bacteriology 55, 31-37.

Fiedler, F. \& SEger, J. (1983). The murein type of Listeria grayi, Listeria murrayi and Listeria denitrificans. Systematic and Applied Microbiology 41, 444450.

Fiedler, F., Seger, J., Schrettenbrunner, A. \& SEeliger, H. P. R. (1984). The biochemistry of murein and cell wall teichoic acids in the genus Listeria. Systematic and Applied Microbiology 5, 360376.

Fryer, J. L. \& Sanders, J. E. (1981). Bacterial kidney disease of salmonid fish. Annual Review of Microbiology 35, 273-298.

Goodfellow, M. \& Cross, T. (1984). Classification. In The Biology of the Actinomycetes, pp. 7-164. Edited by M. Goodfellow, M. Mordarski \& S. T. Williams. London: Academic Press.

Grange, J. M. (1978). Fluorimetric assay of mycobacterial group specific hydrolase enzymes. Journal of Clinical Pathology 31, 378-381.

Grange, J. M. \& Clark, K. (1977). Use of umbelliferone derivatives in the study of enzyme activities of mycobacteria. Journal of Clinical Pathology 30, 151153.

Hucker, G. L. \& ConN, H. J. (1923). Methods of Gram staining. Technical Bulletin of the New York State Agricultural Experimental Station no. 93.

HolmberG, K. \& Hallander, H. O. (1973). Numerical taxonomy and laboratory identification of $\mathrm{Bac}$ terionema matruchotii, Rothia dentocariosa, Actinomyces naeslundii, Actinomyces viscosus, and some related bacteria. Journal of General Microbiology 76, 43-63.

JONES, D. (1975). A numerical taxonomic study of coryneform and related bacteria. Journal of General Microbiology 87, 52-96.

Kovacs, N. (1956). Identification of Pseudomonas pyocyanea by the oxidase reaction. Nature, London $168,703$.

Kusser, W. \& Fiedler, F. (1983). Murein type and polysaccharide composition of cell walls from Renibacterium salmoninarum. FEMS Microbiology Letters 20, 391-394.

Ordal, E. J. \& EarP, B. J. (1956). Cultivation and transmission of the etiological agent of kidney disease in salmonid fish. Proceedings of the Society for Experimental Biology and Medicine 92, 85-88.

SANDERS, J. E. \& Fryer, J. L. (1978). Corynebacterium salmoninus sp. nov. The causative agent of bacterial kidney disease; selected biochemical properties and pathogenesis in salmonid fishes. Proceedings of the Joint 3rd Biennial Fish Health Section and 9th Annual Midwest Fish Disease Workshops, Kansas City, Mo., USA, pp. 28-33.

SANDERS, J. E. \& Fryer, J. L. (1980). Renibacterium salmoninarum gen. nov., sp. nov., the causative agent of bacterial kidney disease of salmonid fish. International Journal of Systematic Bacteriology 30, 496 502.

Schleifer, K. H. \& Kandler, O. (1972). Peptidoglycan types of bacterial cell walls and their taxonomic implications. Bacteriological Reviews 36, 407-477.

SIERRA, G. (1957). A simple method for the detection of lipolytic activity of microorganisms and some observations on the influence of the contact between cells and fatty substrates. Antonie van Leeuwenhoek 23, 15-22.

Schofield, G. M. \& SchaAl, K. P. (1981). A numerical taxonomic study of members of the Actinomycetaceae and related taxa. Journal of General Microbiology 127, 237-259.

SMITH, I. W. (1964). The occurrence and pathology of Dee Disease. Freshwater and Salmon Fisheries Research no. 34. Edinburgh: Her Majesty's Stationery Office.

SNEATH, P. H. A. (1957). The application of computers to taxonomy. Journal of General Microbiology 17, 201-226.

SNEATH, P. H. A. (1978). Classification of microorganisms. In Essays in Microbiology, pp. 9/1-9/31. Edited by J. R. Norris \& M. H. Richmond. Chichester: John Wiley.

SNEATH, P. H. A. \& Johnson, R. (1972). The influence on numerical taxonomic similarities of errors in microbiological tests. Journal of General Microbiology 72, 377-392.

SNeATH, P. H. A. \& Sokal, R. R. (1973). Numerical Taxonomy. London: W. H. Freeman.

Sneath, P. H. A. \& Stevens, M. (1967). A divided Petri dish for use with multipoint inoculators. Journal of Applied Bacteriology 30, 495-497.

SOKAL, R. \& Michener, C. D. (1958). A statistical method for evaluating systematic relationships. Kansas University Science Bulletin 38, 1409-1438.

Stackebrandt, E. \& Woese, C. R. (1979). A phylogenetic dissection of the family Micrococcaceae. Current Microbiology 2, 317-322.

StackebrandT, E. \& Woese, C. R. (1981). The evolution of prokaryotes. In Molecular and Cellular Aspects of Microbial Evolution, pp. 1-31. Edited by M. J. Carlile, J. F. Collins and B. E. B. Moseley. Cambridge: Cambridge University Press.

Stackebrandt, E., Fowler, V. J., Fiedler, F. \& SEILER, H. (1983). Taxonomic studies on Arthrobacter nicotianae and related taxa: description of Arthrobacter sulfureus sp. nov. and reclassification of Brevibacterium protophormiae as Arthrobacter protophormiae comb. nov. Systematic and Applied Microbiology 4, 470-486.

Vladík, P., Vitovec, J. \& Červinka, S. (1974). The taxonomy of Gram-positive immobile diplobacilli 
isolated from necrotizing nephroses in American char and rainbow trout. Veterianami medicina 19 , 233-238.

Weiss, N., Schleifer, K. H. \& Kandler, O. (1981). The peptidoglycan types of Gram-positive anaerobic bacteria and their taxonomic implications. Revue de l'Institut Pasteur, Lyon 14, 3-12.

Wellington, E. M. H. \& Williams, S. T. (1979).
Preservation of actinomycete inoculum in frozen glycerol. Microbios Letters 6, 151-157.

WILKINSON, B. J. \& JoNES, D. (1977). A numerical taxonomic survey of Listeria and related bacteria. Journal of General Microbiology 98, 399-421.

WiShaRT, D. (1978). Clustan User Manual, Version IC, release 2, 3rd edn. Edinburgh: Edinburgh University Program Library Unit. 